\title{
Some Properties of the Complement-fixing Antigens of the Agents of Trachoma and Inclusion Blennorrhoea and the Relationship of the Antigens to the Developmental Cycle
}

\author{
By P. REEVE and JANICE TAVERNE \\ M.R.C. Trachoma Research Unit, The Lister Institute of Preventive Medicine, \\ Chelsea Bridge Road, London, S.W. 1
}

(Received 21 July 1961)

SCMMARY

The viruses of trachoma and inclusion blennorrhoea, like other members of the psittacosis-lymphogranuloma group, contain heat-stable and heatlabile complement-fixing antigens. The heat-stable antigen, which is soluble in ether and partly destroyed by periodate, appears to be chemically similar, as well as serologically related to, the lipopolysaccharide-protein complex shared by other viruses of the group. Complement-fixing group antigen was detected at all times during one cycle of multiplication of a strain of inclusion blennorrohea virus in HeLa cells. The amount of cellassociated antigen, about half of which sedimented under the same conditions as mature elementary bodies, remained constant for the first $16 \mathrm{hr}$. after adsorption; after $16 \mathrm{hr}$. it increased linearly, reaching a maximum $28 \mathrm{hr}$. after adsorption. The group antigen probably forms at a stage in the developmental cycle when large forms predominate and is later distributed among the smaller infectious elementary bodies.

\section{INTRODUCTION}

Bedson (1936) first observed that psittacosis virus possesses both heat-labile and heat-stable complement-fixing antigens. The heat-stable antigen, which is shared by other viruses of the same group (Bedson, Barwell, King \& Bishop, 1949; Monsur \& Barwell, 1951 ; Ross \& Gogolak, 1957) is partly destroyed by periodate (Barwell, 1952; Sigel \& Pollikoff, 1953) is soluble in ether (Hilleman \& Nigg, 1946) and is associated with a phosphatide (Volkert \& Christensen, 1954). Benedict \& O'Brien (1956) found the periodate-sensitive fraction of group antigen extracted from feline pneumonitis with sodium lauryl sulphate to be a lipopolysaccharide, whereas the fraction which resists treatment with periodate is a protein. We have found that the viruses of trachoma and inclusion blennorrhoea are antigenically similar to other members of the group and have investigated the relationship of the lipoprotein-polysaccharide group antigen to infective virus, by following its development during one cycle of multiplication of inclusion blennorrhoea virus in HeLa cells. 


\section{METHODS}

HeLa cells. Monolayers of HeLa cells were grown in $250 \mathrm{ml}$. Pyrex feeding bottles. Each bottle contained $10 \mathrm{ml}$. medium consisting of Hanks's saline solution containing $10 \%(\mathrm{v} / \mathrm{v})$ human serum, $5 \%(\mathrm{v} / \mathrm{v})$ calf serum, $0.5 \%(\mathrm{w} / \mathrm{v})$ lactalbumin hydrolysate and 1,000 units streptomycin $/ \mathrm{ml}$.

Viruses. The following strains were used:

Trachoma: TE 55 (T'ang, Chang, Huang \& Wang, 1957);

LT1 (Jones, 1961).

Inclusion blennorrhoea :

L13 1 (Jones, Collier \& Smith, 1959);

LB 2, LB3 and LB4 (Jones, 1961).

Disruption of HeLa cells. Infected cells were suspended in $5 \mathrm{ml}$. diluent (see below) and submitted for $4 \mathrm{~min}$. to a frequency of $20 \mathrm{kc}$./sec. produced by an MSEMullard ultrasonic disintegrator with a power output of $60 \mathrm{~W}$. (Furness, Graham \& Reeve, 1960).

Diluent. The diluent used consisted of $0.02 \mathrm{M}-\mathrm{H}_{3} \mathrm{BO}_{3}, 0.0008 \mathrm{M}-\mathrm{Na}_{2} \mathrm{~B}_{4} \mathrm{O}_{7}, 0.0007 \mathrm{M}-$ $\mathrm{CaCl}_{2}, 0.003 \mathrm{M}-\mathrm{MgCl}_{2}$ and $0.15 \mathrm{M}-\mathrm{NaCl}$ in distilled water, to which was added $2 \%$ (v/v) heated normal guinea-pig serum.

Antigens. Virus grown in yolk sac or $\mathrm{HeLa}$ cells was sedimented at $8000 \mathrm{~g}$ for $40 \mathrm{~min}$. at $4^{\circ}$ and resuspended in a volume of diluent giving at least a ten-fold concentration of the original virus suspension. When required, antigens were heated for $30 \mathrm{~min}$, at $100^{\circ}$ in a water bath.

Periodate treatment. Equal volumes of antigen and $0.025 \mathrm{M}-\mathrm{KIO}_{4}$ in $0 \cdot 15 \mathrm{M}-\mathrm{NaCl}$ were mixed and incubated at $37^{\circ}$ for $30 \mathrm{~min}$. A drop of the mixture liberated iodine from a drop of $1 \%(\mathrm{w} / \mathrm{v}) \mathrm{KI}$ in $0.2 \mathrm{~m}$-phosphate buffer ( $\mathrm{pH} 7 \cdot 0$ ), indicating that $\mathrm{KIO}_{4}$ was in excess, and this excess was then neutralized with $20 \%(\mathrm{w} / \mathrm{v})$ glucose.

Antiserum. Rabbits were immunized by intravenous injection of yolk-sac or cellculture suspensions of virus (Recve \& Graham, 1962). Virus suspensions were administered to guinea pigs intranasally. Sera were stored at $-40^{\circ}$ and were heated for $30 \mathrm{~min}$. at $56^{\circ}$ before use.

Complement. Fresh guinea-pig serum stored at $-40^{\circ}$ was used.

Complement fixation. Antigens were titrated by the method of Fulton \& Dumbell (1949), with a $1 / 20$ dilution of antiserum known to give maximum fixation with concentrated antigen. Reaction mixtures were left at $4^{\circ}$ overnight before the haemolytic system was added, since this more than doubled the amount of complement fixed. Dilutions of antigen were plotted against $\log _{10}$ units of complement fixed; the antigen titre was taken as the reciprocal of the dilution fixing 1 unit of complement.

Growth cycle experiments. HeLa cell monolayers were inoculated with $2 \mathrm{ml}$. of a suspension of virus, obtained from ultrasonically disrupted cells, at a concentration known from routine infectivity titrations to infect every cell (Furness et al. 1960). Virus was allowed to adsorb for 4-6 hr. at $30^{\circ}$; unadsorbed virus was then decanted, the monolayers washed twice with $10 \mathrm{ml} .0 \cdot 15 \mathrm{M} \cdot \mathrm{NaCl}$, then $10 \mathrm{ml}$. tissue culture medium added and the cultures incubated at $37^{\circ}$. Immediately after adsorption the antigen present in the cells in two $250 \mathrm{ml}$. bottles when concentrated 20 -fold 
could only just be detected by complement fixation. Therefore, the cells from 10 bottles were pooled for each sample taken at intervals during a growth cycle and the antigen obtained from them was concentrated 100-fold in the following way. The medium from 10 bottles was decanted and pooled, and the monolayers washed twice and placed at $-40^{\circ}$. At the end of the experiment, all the infected cells from each batch were suspended in $5 \mathrm{ml}$. diluent, disrupted, centrifuged and the deposit resuspended in $1 \mathrm{ml}$. diluent. The supernatant fluid will be referred to as 'soluble cellular antigen' and the deposit as 'sedimentable cellular antigen'. Pooled tissue culture medium from cach sample was also centrifuged and the deposit, resuspended in $1 \mathrm{ml}$. of diluent, will be called 'extracellular sedimentable antigen'.

\section{RESULTS}

Antiserum prepared against yolk-sac virus was always used to titrate tissue culture antigens; antiserum against cell-cultured virus was used with yolk sac antigens. Thirty-six replicate titrations of the same antigen by complement fixation revealed a standard deviation of $\pm 10 \%$ so that a two-fold difference of titre is significant at the $95 \%$ level. Trachoma and inclusion blennorrhoca viruses grown in yolk sac or cell culture were repeatedly titrated against homologous and heterologous antisera and, using unabsorbed antisera with either heated or unheated antigens, they could not be distinguished.

Table 1. Effect of heat on different LB 4 virus yolk-sac suspensions

The antigens were titrated with LH 1 antiserum.

\begin{tabular}{cccc} 
& \multicolumn{2}{c}{ Titre } & $\begin{array}{c}\text { Decrease } \\
\text { in titre }\end{array}$ \\
Antigen & $\overbrace{\text { Before heating }}$ & After heating & 6-fold \\
$V_{1}$ & 3840 & 640 & 2 -fold \\
$V_{2}$ & 960 & 480 & 0 \\
$V_{4}$ & 640 & 480 & 0 \\
$V_{7}$ & 1280 & 060 &
\end{tabular}

\section{Composition of group antigen}

Effect of heat. Table 1 gives representative results obtained when four different LB 4 yolk-sac suspensions were titrated with LB 1 antiserum before and after heating. Only two suspensions underwent a significant decrease in titre after boiling. In twenty other titrations the titres of eight antigens were significantly decreased after heating, 11 were unchanged and only one was significantly enhanced. In six titrations with lymphogranuloma venereum (LGV) convalescent serum no alteration in titre occurred. Our results suggest that these viruses possess a heat-labile antigen, although this is not always demonstrable. In contrast to the findings of Rarwell (1952) and others, boiling seldom enhanced the titre of the heat-stable antigen.

Effect of periodate. Table 2 summarizes the effect of different concentrations of potassium periodate on the titre of yolk-sac suspensions of two strains of inclusion blennorrhoea. The titres of both strains were decreased four-fold by all the concentrations tested; a constant fraction of antigen remained resistant to periodate. This 
resistant fraction reacted equally with antisera against three strains of inclusion blennorrhoea, two strains of trachoma and LGV convalescent serum (Table 3).

Two different suspensions of a strain of trachoma virus grown in HeLa cells were treated with periodate and heated (Table 4). Heating alone did not decrease the antigen titres, measured with heterologous antiserum (LGV convalescent serum). Periodate treatment again decreased the antigen titres four-fold, leaving a periodateresistant fraction which was heat-labile and still capable of reacting with heterologous antiserum.

Table 2. Effect of different concentrations of $\mathrm{KIO}_{4}$ on yolk-sac suspensions of two strains of inclusion blennorrhoea, titrated with LB1 antiserum

\begin{tabular}{|c|c|c|c|}
\hline \multirow[b]{2}{*}{ Antigen } & \multirow[b]{2}{*}{$\begin{array}{c}\text { Concentration } \\
\text { of } \mathrm{KIO}_{4}(\mathbf{M})\end{array}$} & \multicolumn{2}{|c|}{ 'Titre } \\
\hline & & $\begin{array}{c}\text { Before } \\
\text { treatment }\end{array}$ & $\begin{array}{c}\text { After } \\
\text { treatment }\end{array}$ \\
\hline LB3 & $\begin{array}{c}0.005 \\
(0.0125\end{array}$ & $\begin{array}{r}128 \\
96\end{array}$ & $\begin{array}{l}28 \\
24\end{array}$ \\
\hline LB 1 & $\left\{\begin{array}{l}0 \cdot 003 \\
0 \cdot 0007\end{array}\right.$ & $\begin{array}{l}96 \\
96\end{array}$ & $\begin{array}{l}24 \\
24\end{array}$ \\
\hline
\end{tabular}

Table 3. Reaction with heterologous antisera of $\mathrm{KIO}_{4}$-resistant fractions of inclusion blennorrhoea and of trachoma viruses groun in HeLa cells

$\begin{array}{lccc}\text { Antigen } & \overbrace{\text { Before }}^{c} & \\ \text { treatment } & \begin{array}{c}\text { After } \\ \text { treatment }\end{array} & \text { Antiserum } \\ \text { LB 1 suspension }(a) & 56 & 28 & \text { LB1 } \\ & 56 & 20 & \text { LT1 } \\ & 56 & 28 & \text { LB2 } \\ & 56 & 16 & \text { I.B4 } \\ \text { LB 1 suspension }(b) & 56 & 16 & \text { TE55 } \\ \text { TE55 } & 64 & 24 & \text { LGV } \\ & 56 & 12 & \text { LGV }\end{array}$

Table 4. Effect of heat and of $\mathrm{KIO}_{4}$ on two different suspensions of trachoma virus (strain TE55) titrated with LGV convalescent serum

\begin{tabular}{|c|c|c|}
\hline \multirow[b]{2}{*}{ Treatment } & \multicolumn{2}{|c|}{ Titre of suspension } \\
\hline & (a) & (b) \\
\hline Control & 58 & 64 \\
\hline Heated & 56 & 48 \\
\hline $0.025 \mathrm{M}-\mathrm{KIO}$ & 12 & 24 \\
\hline $\begin{array}{r}0.025 \times 1-K I O \\
\text { then heated }\end{array}$ & 0 & $\mathbf{G}$ \\
\hline
\end{tabular}

Benedict \& O'Brien (1956) demonstrated similar fractions in a soluble antigen extracted from feline pneumonitis virus; they showed the periodate-sensitive and fraction-resistants to be respectively a polysaccharide and a protein. By inference this is also true of the similar fractions of trachoma and inclusion blennorrhoea viruses. 
Effect of ether. The antigen titre of an unheated suspension of LB lvirus prepared from infected $\mathrm{HeL}$ a cells was not diminished by shaking with ether, and no antigen was detected in the ether extract. When, however, the suspension was boiled before ether treatment, a group reactive antigen was extracted. The ether-soluble antigen was insoluble in methanol and thus appeared to be a phosphatide. Although phospholipids and polysaccharides may fix complement in vitro some may

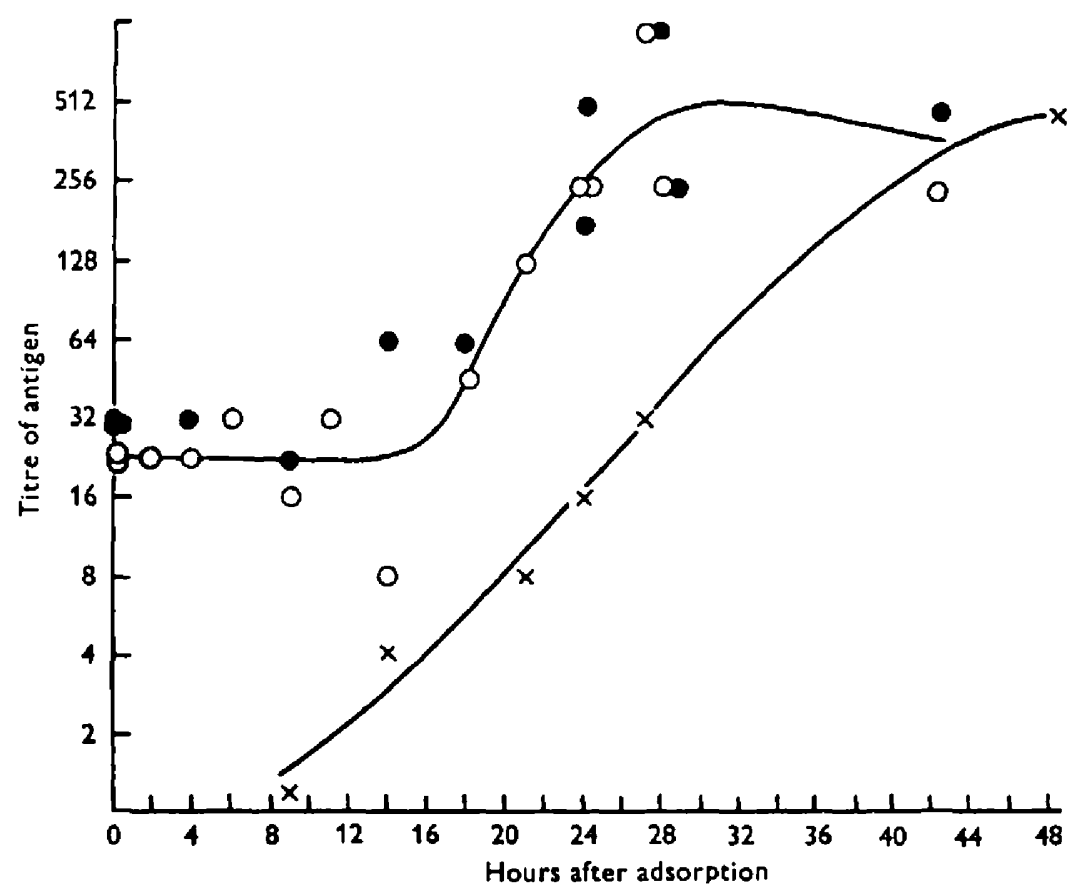

Fig. 1. Development of complement-fixing antigen during one growth cycle of the LB 1 strain of inclusion blennorrhoea in HeLa cells. Titres represent the total amount of antigen present in ten infected monolayers. - - , cellular soluble antigen; $\mathrm{O}-\mathrm{O}$, cellular sedimentable antigen; $\times-x$, extracellular sedimentable antigen.

behave as haptens in vivo, only stimulating antibody formation when combined with protein. That a virus suspension must be boiled before a soluble antigen can be extracted with ether suggests that the antigen is strongly bound to a heat-sensitive component. The evidence suggests that the group antigen is a lipoprotein-polysaccharide complex.

\section{Development of complement-fixing antigen of inclusion blennorrhoea virus in HeLa cells}

On several occasions the complement-fixing antigen present in HeLa cell cultures was titrated at intervals during one growth cycle of the LBI strain of inclusion blennorrhoea virus. Figure 1 shows the results of a representative experiment in which unheated samples were titrated with homologous antiserum. Samples from normal HeLa cells concentrated in the same way did not fix complement with this serum. Each sample was also titrated after treatment with periodate. At each assay both soluble and sedimentable antigen proved heat-stable and a constant 
proportion was destroyed by periodate. Thus, although the virus contains several antigens and the antiserum used was prepared against whole virus, our method could be used to examine only the fate of the lipoprotein polysaccharide group antigen.

During the first $14 \mathrm{hr}$. of infection there was little change in the total amount of ccllular antigen. About half was deposited under the same conditions as whole virus particles, and the rest remained in the supernatant fluid. The amount of sedimentable antigen did not decrease at any time and its increase was not preceded by an increase in soluble antigen. Indecd, throughout the life cycle of the virus, a constant proportion of the group antigen was in the form of this smaller component, suggesting either that the virus is associated with a soluble product, or that a loosely bound outer antigen is stripped off during manipulation.

Antigen appeared to be released continuously throughout the growth cycle, until at $40 \mathrm{hr}$. after adsorption as much antigen was present in the supernatant fluid of infected cultures as could be released from the cells. In contrast, Furness \& Fraser (1961) reported that at $\mathbf{4 2} \mathrm{hr}$. infectious extracellular virus only amounted to $1 \%$ of the infectious virus within the cells. It appears that released virus is rapidly inactivated at $37^{\circ}$ but remains antigenic.

\section{DISCLSSION}

Our experiments suggest that trachoma and inclusion blennorrhoea viruses contain antigens similar to the lipoprotein polysaccharide complex of feline pneumonitis described by Benedict \& O'Brien (1956). The complement-fixing component of an intact particle is likely to be at the surface; and Jenkin (1960), working with meningopneumonitis, believed that in the intact particle the group antigen resided in the cell wall. Therefore, study of the group antigen may reveal the behaviour of the cell wall of the virus during its life cycle.

The life cycles of members of the psittacosis-lymphogranuloma venereum (LGV) group of viruses have been studied by many workers from the point of view of morphology and development of infective particles (see Wenner, 1958, for recent review; IIgashi, Natake \& Fukada, 1959; Furness \& Fraser, 1962); less work has been done on the development of complement-fixing antigens. Bedson \& Gostling (1954) studied the production of group antigen in the spleens of mice infected with psittacosis; Officer \& Brown (1960) measured the group antigen formed during the growth of psittacosis virus in cell culture. In neither study was antigen detected before the 16 th hr. after infection.

Our experiments establish two facts. First, the antigen can be detected throughout the growth cycle and, secondly, the amount of antigen increases at least $6 \mathrm{hr}$. before all the adsorbed virus increases in infectivity (Furness \& Fraser, 1962). Investigation of other members of the group by several different techniques indicates that although the viruses are not infectious during the first $14 \mathrm{hr}$. after adsorption they do not lose their identity. Thus, elementary bodies of meningopneumonitis virus staining with Macchiavello's stain were seen in $L$ cells up to $14 \mathrm{hr}$. after infection (Higashi et al. 1959); particles containing DNA were detected up to $4 \mathrm{hr}$. after infection of human amnion cells with psittacosis virus (Pollard, Starr, Moore \& Tanami, 1960); and psittacosis virus particles combining 
with fluorescent antibody were present in the cytoplasm of mouse-embryo liver cells 1, 3, 5 and $8 \mathrm{hr}$. after infection (Buckley, Whitney \& Rapp, 1955). Neither Bedson \& Gostling (1954) nor Officer \& Brown (1960) detected complementfixing antigens of psittacosis virus until $16 \mathrm{hr}$. after the start of the growth cycle, but in neither study was the amount of virus adsorbed detected by complement fixation, suggesting that the methods used were insufficiently sensitive to detect antigen until some multiplication had occurred. By concentrating the virus we were able to detect the antigen adsorbed at the start of the growth cycle, and to show that antigen persisted in the cells during the early stages.

The amount of complement-fixing antigen increased when the large basophil particles, rich in RNA (Pollard et al. 1960; Furness, Henderson, Csonka \& Fraser, to be published) increased in amount. These large forms are the only structures with which the sedimentable cellular antigen could be associated; Buckley and co-workers (1955) demonstrated that the large forms of psittacosis virus react with fluorescent antibody. Twenty-four hours after infection, when the amount of antigen has reached its maximum, less than $10 \%$ of the adsorbed virus is infectious (Furness \& Fraser, 1961). Much of the antigen latcr associated with elementary bodies is apparently formed earlier during the development of the large forms.

Our results support Higashi's interpretation of the life cycle of this group of microorganisms (Higashi, 1959), since the antigen persists unchanged during the noninfective phase. The large forms, which are rich in RNA, may be regarded as a vegetative stage during which most synthesis, including that of the cell-wall components, takes place.

We are grateful to Miss Elizabeth Fraser for supplying HeLa cell cultures.

Sera from patients with lymphogranuloma venereum were generously supplied by Dr Sylvia Read, London Hospital, Whitechapel, and Dr G. Csonka, St Mary's Hospital, London.

\section{REFERENCES}

Barwell, C. F. (1052). Some observations on the antigenic structure of psittacosis and lymphogranuloma viruses. II. Treatment of virus suspensions by various reagents and the specific activity of acid extracts. Brit. J. exp. Path. 33, 268.

Beuson, S. P. (1936). Observations bearing on the antigenic composition of psittacosis virus. Brit. J. exp. Path. 17, 109.

Beoson, S. P., Barwell, C. F., King, F. J. \& Bishop, L. W. J. (1949). The laboratory diagnosis of lymphogranuloma. J. clin. Path. 2, 241.

Bedson, S. P. \& Gostins, J. V. T. (1954). A study of the mode of multiplication of psittacosis virus. Brit. J. exp. Path. 35, 299.

Benedict, A. A. \& O'Briev, L. (1956). Antigenic studies on the psittacosis-lymphogranuloma venereum group of viruses. II. Characteristics of complement-fixing antigen extracted with sodium lauryl sulfate. J. Immunol. 76, 293.

BUCKI.EY, S. M., Whitsey, E. \& RAPr, F. (1955). Identification by fluorescent antibody of developmental forms of psittacosis virus in tissue culture. Proc. Soc. exp. Riol., N.Y. 90, 226.

Fulton, F. \& Dumnelu, K. R. (1949). The serological comparison of strains of influenza virus. J. gen. Microbiol. $3,97$.

Funness, G. \& Fraser, E. F. (1962). One-step growth curves for inclusion blennorrhoea virus in Hela cell monolayers. J. gen. Microbiol, 27, 299.

Furness, G., Gramam, D. M. \& Refeve, P. (1960). The titration of trachoma and inclusion blennorrhoea viruses in cell cultures. J. gen. Microbiol. 23, 613. 
Higashi, N. (1959). Some fundamental differences of the mechanism of multiplication between psittacosis group viruses and pox viruses. Ann. Keport Inst. Virus Research, Kyoto Univ., Series B, 2, 1.

Higashi, N., Notake, K. \& Fukada, T. (1959). Growth characteristics of the meningopneumonitis virus in strain L cells. Ann. Report Inst. Virus Research, Kyoto Univ., Series $B, 2,23$.

Hildemai, M. R. \& Nigo, C. (1946). Studies on lymphogranuloma venereum complementfixing antigens. III. The solubility in ether of an active fraction. J. Immunol. 53, 201.

Jenkins, H. M. (1960). Preparation and properties of cell walls of the agent of meningopneumonitis. J. Bact. 80, 639.

Jones, B. R. (1961). TRIC virus infection in London. Trans. Ophthal. Soc. U.K. 8, 367.

Jones, B. R., Collier, L. H. \& Smith, C. H. (1958). Isolation of virus from inclusion blennorrhoea. Lancet, i, 902.

Monsuk, K. A. \& Barwell, C. F. (1951). Observations on the antigenic relationship between the virus of enzootic abortion of ewes and viruses of the psittacosis-lymphogranuloma group. Brit. J. exp. Path. 32, 414.

OfFickr, J. E. \& Brown, A. (1960). Growth of psittacosis virus in tissue culture. J. infect. Dis. $107,283$.

Pollard, M., Stark, T. J., Moore, R. W. \& Tanami, Y. (1960). Cytochemical changes in human amnion cells infected with psittacosis virus. Nature, Lond. 188, 770.

Reeve, P. \& Graham, D. M. (1962). J.gen. Microbiol. 27, 177.

Ross, M. R. \& Gogolak, F. M. (1957). The antigenic structure of psittacosis and feline pneumonitis viruses. I. Isolation of complement-flxing antigens with group and species specificity. Virology, 3, 343.

Siget, M. M. \& Polmkoff, R. (1953). Reduction of group reactivity of complementfixing antigen of meningo-pneumonitis virus by potassium periodate. Proc. Soc. exp. Biol., N.Y. 84, 517.

T'ang, F. F., Chang, H. L., HVang, Y. T. \& Wang, K. C. (1957). Studies on the etiology of trachoma with special reference to isolation of the virus in chick embryo. Chin. med. J. 75, 429.

Volkert, M. \& Christensen, P. M. (1954). Studies on ornithosis in Denmark. Acta path. microbiol. scand. 35, 584.

Wenner, H. A. (1958). Psittacosis-lymphogranuloma venereum group of viruses. Advanc. Virus Res. 5, 39. 